\title{
Saadia on "what is in the hearts of people when they reach the limits of endurance in a trial"
}

Josef Stern

Saadia ben Joseph Al-Fayyumi Gaon (b. Egypt 882, d. Iraq 942) is one of the best examples of the impact of Islamic civilization (which absorbed Late Ancient culture and thought) on medieval Judaism in the East. The most distinguished rabbinic scholar of his generation, he was "Gaon" ("His Excellency"), or Head, of the famous Talmudic academy in Sura and later in Baghdad (under the Abbasids), the author of important legal responsa and treatises, especially on procedural law and on the calendar, and a powerful opponent of the sectarian Karaites. He also wrote pioneering work on Hebrew linguistics and grammar, poetry, and liturgy; translated the Hebrew Bible into Arabic; and composed commentaries on

Earlier versions of this paper were given at the Munich School of Philosophy, Bar-Ilan University, and Kehillat Kol Dodi, Jerusalem. I wish to thank Eleonore Stump, Godehard Bruntrup, Kelly Clark, Shira Weiss, and Umeyye Isra Yazicioglu for comments and criticism.

J. Stern $(\bowtie)$

The University of Chicago, Chicago, IL, USA

e-mail: j06s@uchicago.edu

(C) The Author(s) 2022

K. J. Clark, J. Koperski (eds.), Abrahamic Reflections on

Randomness and Providence, https://doi.org/10.1007/978-3-030-75797-7_16 
selected books, including the Book of Job. However, he is probably best known for his Book of Doctrines and Beliefs, a book of Jewish kalam, socalled dialectical theology, an attempt to systematize the beliefs of Judaism and, arguably, the first book of Jewish philosophy (in a broad sense of the term "philosophy," although it is not Aristotelian falsafa $).{ }^{1}$ It was the first such text to initiate a tradition of Jewish thought. ${ }^{2}$

In the fourth and fifth treatises of Doctrines and Beliefs and, as we shall see, in the Introduction to his commentary on the Book of Job, The Book of Theodicy, Saadia discusses the constellation of metaphysical issues that revolve around providence, the problem of evil, free will and human responsibility, reward and punishment, suffering, and, in particular, unjust or undeserved suffering, which is known in rabbinic Judaism as the problem of zaddiq ve-ra' ' $l o$ '(the suffering of the righteous) and rasha' ve-tov lo' (the prospering of the wicked). First, Saadia defends a libertarian conception of human freedom against strong Ash'arite arguments that deny it in order to secure divine omnipotence manifest in occasionalism, the doctrine that there are no intermediate natural causes and that all natural phenomena, including human action, are directly causally dependent on the will of God. On Saadia's view, God gave humans the freedom to act including the ability to commit moral wrongs. However, while He allows such evils - after all, the harm their free actions cause is not to Him but to themselves - at the same time He warns humans not to commit them out of His mercy for humanity. The fact that humans commit those evils is, in any case, neither incompatible with His power (to do only the good) nor does it show that He lacks power (over humanity). Second, in order to demonstrate the compatibility of natural evil, or suffering, with the

\footnotetext{
${ }^{1}$ Doctrines and Beliefs was not, however, the first book of Jewish kalam. That distinction goes to al-Muqammas 2016 (9th c.) which is also the first Arabic theological treatise we possess.

${ }^{2}$ For the major works of Saadia, see Saadiah 1946/2002; 1948; 1972; 1973; 1988. All citations in the text to Doctrines and Beliefs are to Saadiah 1946/2002 (Altmann translation) and all citations in the text to the Commentary on Job are to Saadiah 1988 (Goodman translation). For Saadiah's intellectual biography and especially the Islamic background to his life and thought, see Malter 1921; Brody 2016; and Stroumsa 2003. On the Commentary on Job, and its Islamic background, both in the Qur'an and tafsir literature, see Goodman's introductory essay to Saadiah 1988, 4-109; Goodman 1990; Stump 1997; 2000; Rosenthal 2001, 97-125; Eisen 2004, 17-41; and Cohen 2005, 243-253. On Saadiah's general theory of providence, see Stump 1997 and Nadler 2009, 624-628. On Saadiah's epistemology, see Heschel 1942-3 and 1944-5. On the significance of traditions in the characterization of Jewish philosophy and Saadiah's place in a tradition, see Josef Stern 2017.
} 
existence of God and, more important for Saadia, with divine justice, he offers a number of traditional theodicies: that natural evil is an illusion if one were only to know the "big picture," that there are no goods without evils, and that evils are often corrective devices. However, the problem of evil that most concerns Saadia is that of the suffering of the righteous and the prosperity of the wicked. Not only is this unjust. According to Saadiah, it challenges the very idea of reward and punishment. His general reply is that while there is reward and punishment, we can never know who is truly deserving of either. Thus he attempts to disabuse us of one problem with evil-Why are we suffering and what did we do wrong?-by constructing an account that both affirms that there is a theodicy, or justification for all evil, and delimits human understanding of how to apply such a theodicy to actual cases.

More specifically, Saadia's theodicy to account for the suffering of the righteous distinguishes two kinds of suffering or evil: (i) punishment and (ii) trial or testing.

I find that suffering befalls the pious in this world in one of two ways: either as punishment for the relatively small number of their transgressions ... or, alternatively, as a visitation from God in order to test them, provided $\mathrm{He}$ knows that they will be able to endure it. Later he compensates them for their suffering. (Saadiah 1946/2002, 137-8)

When sufferings and calamities befall us, they must be of one of two classes: either they occur on account of prior sins of ours, in which case they are to be called punishments, and we must search out the relevant shortcomings and remove them and improve our actions. ... Or they are a trial from the Allwise, which we must bear steadfastly, after which He will reward us. (Saadiah 1988, 130)

The first justification for suffering is that it is punishment for past sins and wrongs. However, the function of the suffering is not only retribution but also purification of the sinner's soul of lasting bad effects on his dispositions and character as a result of his individual sinful actions. People's actions, good and bad, leave their traces on their souls, rendering them either pure or sullied. One function of suffering is to correct, purify, or cleanse the soul of any defect or unclean stain on the sinner's character or personality, and to restore it to its pristine condition. But only God can discern the flaws in the soul and recognize whether there are long-term 
effects on our dispositions and characters. Hence, humans can never know-especially about others-why in particular they suffer, although the fact that they suffer should be attributed to just desert.

Understanding suffering as punishment is complicated by the fact, Saadia argues, that no one is either purely righteous or purely wicked. If someone fell in a single category, the purely righteous or the purely wicked, there would be no difficulty in explaining why he prospers or suffers, respectively. But generally humans are a mix of the righteous and the wicked. Thus divine justice demands that even the very wicked receive their due for good actions or virtues, and analogously for the very righteous, for their sins. Therefore, reward and punishment cannot be measured as simple one-to-one effects of or reactions to individual actions; they require calculation and computation, balancing good with evil and the evaluation of punishment and reward in a more holistic fashion, looking at the whole person, not just his isolated acts, one by one. Only God can know how to do this.

Saadia distinguishes two worlds: a "world of action," this world in which we humans live and act, and a "world of reward," a world in which human actions receive their compensation, reward or punishment. This second world according to Saadia is not necessarily "the world to come" in rabbinic terminology, the afterlife, paradise or hell. It is closer to a posthistorical age like the messianic era in which it is humans (perhaps resurrected), not disembodied souls, who are compensated. However, the fact that there exists a dedicated world for compensation does not mean that there is no evidence of reward or compensation in this world, the world of action. The true rewards may all come in the world of compensation but there is also some reward or compensation in the world of action, both to signal to humans that there exists a future world of compensation and, more important, because individuals are typically a mix of righteousness and wickedness and therefore demand both reward and punishment. In other words, the innocent are never totally innocent, nor are the wicked totally wicked. If "entrance" to the (sub-?) world (only) of reward is only for those who are due reward exclusively (and analogously for the (sub-?) world of punishment), what of the mixed cases? They cannot enter either world. Therefore, the Divine Bookkeeper calculates each individual's good and bad deeds and then rewards/punishes that class of deeds that are in the minority in this world of action in order to enable her soul to enter the (sub-)world of reward (or punishment, as the case may be) in a "pure" position. Because even the righteous have slight failings, given divine 
bookkeeping, they are punished in this world and likewise for the wicked who are rewarded in this world. However, this explanation solves the problem only insofar as the punishments (and rewards) in this world of action are commensurate to the supposed minor acts of wickedness for the righteous (and minor acts of righteousness for the wicked). But most cases of the suffering of the righteous appear to be exactly the opposite: the more righteous the sufferer, the more incommensurate seem to be the evil acts that are called upon to justify her suffering. Thus, the overall moral of this quantified, economic model of suffering serves to underscore our human ignorance of how to calculate virtues and vices to determine reward and punishment. One should never draw inferences about desert and justice for any particular individual from either her prosperity or her suffering.

The second kind of justification for suffering and evil is what Saadia calls "trials and testing." These are not correctives for prior sins, but showtrials enacted by God to reveal to the world at large the piety of those tested. Enduring such show-trials demonstrates the piety of the sufferer to the whole world. However, if that is the purpose of the trial, one might nonetheless object that the suffering is not deserved. No past wrongs that the sufferer committed justify why he should be subject to evil. In order to address this objection and thereby render the suffering just, or at least seem fair, Saadiah argues that the trial leads to compensation or a greater reward $(g e m u l)$ in the future for the sufferer, either in the temporal future or in the afterlife. In return for suffering now, the victim, or sufferer, is compensated in the future.

This second justification, the so-called doctrine of compensation, which is also identified with the rabbinic notion of "sufferings of love," is severely criticized by Maimonides in the Guide of the Perplexed, and Saadia is clearly his target although he is not mentioned by name $(1965,498,471)$. "God sends down calamities upon an individual, without their having been preceded by a sin, in order that his reward be increased" (Maimonides 1965, 497). But even if the victim is ultimately "paid back" for his losses and suffering with a greater reward at some time in the future, Maimonides objects that the suffering was undeserved at the time of the suffering and therefore it was unjust then. Nor is it obvious that any individual would willingly undergo suffering only for the promise of future compensation. So insofar as the suffering is not what the individual wants, even if the compensation is fair, it is not something the individual desires, hence, not good for him. In sum, although this explanation is, Maimonides grants, 
"generally accepted among people" (498), no one "endowed with intellect" (497) would believe such an impious opinion about God.

To recap, Saadiah offers two solutions, or theodicies, for the metaphysical problem of the suffering of the righteous human: punishment and trial. In addition, he gives a third account in the Commentary that suffering is simply part of, or constitutive of, being a created substance.

God created human beings in the first place to test them. (Saadiah 1988, 129)

The very reason for creating finite humans was to enable them to manifest their ability to survive or endure suffering-and to endure it autonomously, that is, through their reason. To be sure, they will be compensated, but on this explanation suffering is the rule, not the exception, for created life.

Saadia's clearest example of such suffering built into createdness is what I will call epistemic evil: doubt and uncertainty. Saadiah tells us that he wrote Doctrines and Beliefs because of the pervasive doubt among his coreligionists at his time, his contemporaries' lack of certainty and security in their beliefs, their many false or at least unjustified beliefs, and a kind of pervasive relativism due to their cosmopolitan culture.

When I considered these evils ..., my heart grieved for my race, the race of mankind ... as I saw in my time many of the believers clinging to unsound doctrines and mistaken beliefs. ... I saw men sunk, as it were, in a sea of doubt covered by the waters of confusion. (Saadiah 1946/2002, 28-29, my emphasis)

This leads him to ask:

How can it be reconciled with the wisdom of the Creator ... that he allowed errors and doubts to arise in the minds of His creatures? We may answer this question at once by saying that the very fact that they are created beings causes them to be subject to error and delusion. (Saadiah 1946/2002, 31)

That is, error and doubt are a natural evil that comes with being a human and one must learn to live with it. Indeed

To wish to have "knowledge that is free from doubt" is "to ask to be nothing less than like God." (Saadiah 1946/2002, 33) 
Being human is being subject to doubt and uncertainty. But doubt and uncertainty are themselves evils and forms of suffering, both epistemic and psychological.

With this background, I now want to turn to Saadia's Commentary on the Book of Job, his Book of Theodicy. As I have already indicated, Saadia discusses the metaphysical problem of evil in his Introduction to his Arabic translation and commentary, more or less repeating the justifications he presents at greater length in Doctrines and Beliefs. ${ }^{3}$ However, I will argue that the main issue with which he is concerned in the commentary itself is not the metaphysical problem and its solutions, or theodicies. Rather the issue is what I shall call the existential problem of evil:

Knowing that throughout the ages the thoughts which pass before men's minds when sufferings befall them are of four sorts, corresponding to those which arose in Job's day, God required all this to be set forth for us. ... Thus God caused the record of Job's trials and afflictions to be set forth-his words, the words of his companions, the arguments of each, as well as Elihu's rebuttal-with the purpose of revealing by this means what is in the hearts of people when they reach the limits of endurance in a trial. (Saadiah $1988,127)$

What we learn from the Book of Job is not metaphysics-the compatibility of evil and suffering with the existence of God or with divine justicebut what people enduring and witnessing suffering are thinking when they suffer, their experience of suffering, how they react to suffering - and, perhaps, in turn, how we ought to react to our own suffering. Thus Saadiah wants to give us primarily a phenomenology of suffering although sometimes he seems to slip from the descriptive to the normative, from what people are thinking to what they ought to be thinking.

Saadia's pursuit of this problem is itself highly original. I know of no other medieval Jewish thinker who poses such a question. As important, it is a problem that can be explored best, perhaps only, through a commentary on a narrative like Job, not through discursive philosophical analysis and traditional forms of argument or proof. Saadia was not, of course, the only medieval Jewish, Muslim, or Christian philosopher to write both philosophical treatises (or commentaries on earlier philosophical works) and philosophical commentaries on Scripture. However, when an author

\footnotetext{
${ }^{3}$ Weiss 2000 and Eisen take the Commentary primarily to recapitulate Doctrines and Opinions.
} 
engages in different genres of philosophical writing (like these), one naturally wonders whether the one form enables her to address and explore issues that the other does not, or not as well or in different way. And how does the genre of writing affect how the author deals with the same problem in the different works? In particular, does a narrative or dialogue allow the author to address subtle questions from more perspectives than philosophical exposition? ${ }^{4}$ For example, in the passage just quoted, Saadia writes that it is from the words of all the figures in the book, not from any one speaker, that we learn "the thoughts which pass before men's minds when sufferings befall them." The "record" of Job consists not only in Job's words but equally in "the words of his companions, the arguments of each, as well as Elihu's rebuttal." No single character expresses what is revealed about "what is in the hearts of people," only the totality of different perspectives, each partial and even potentially in conflict with one another. The opportunities made possible by the dialogue form in Job are reminiscent of Hume's explanation in the opening to his Dialogues Concerning Natural Religion in Hume 1779 (1993) of why he employs the genre of the dialogue: to explore a topic "where human reason can reach no fixed determination," where "reasonable men may be allowed to differ," and "where the variety of lights, presented by various personages and characters, may appear neither tedious nor redundant" (29-30). Is there something about the problem of evil, or God's relation to the world, that makes it especially appropriate for treatment in the dialogue form?

The task Saadia sets for himself in the Commentary on Job is not only novel and original. The commentary is a seminal work of scriptural exegesis and interpretation for at least two additional reasons. First, Saadiah gives radically naturalistic interpretations, downplaying, if not eliminating, the fantastic, mythical, supernatural elements in the biblical text, features that were emphasized and expanded upon in earlier rabbinic midrashic exegesis. For example, the Leviathan becomes a crocodile in Saadia's hands, and Behemoth, a hippopotamus or cattle. These are exotic animals but not mythical or fantastic creatures. And we will turn next to Saadiah's most naturalistic de-mythicizing interpretation of the narrative frame of the book.

Second, Saadia was the first, to my knowledge, to reconstruct the rambling, repetitious speeches of the three friends and of Elihu, Job, and God as philosophical arguments, identifying theses for which they argue that

\footnotetext{
${ }^{4}$ For an intensive exploration of this question, see Stump 2010, ch. 9.
} 
serve as objections and responses to each other, thereby shaping each figure's speech into a "coherent" philosophical position, turning the book into a philosophical dialogue between different philosophical schools. Each character represents a different school—an idea that, in turn, will be borrowed by Maimonides in his interpretation of Job in the Guide, although the schools Saadia and Maimonides find in the book are not the same. So, for Saadia, Job is initially an Ash'arite: his God does whatever He wants without constraint, and justice is whatever God so decides. The three friends are all Mut'azalites: they insist that everything God does is just (in our sense of the term); hence, Job must have sinned for which he suffers as punishment. Elihu is a revised Mut'azalite (probably speaking for Saadiah himself) who introduces the doctrine of compensation and trials in addition to suffering and punishment. However, as Saadia emphasizes a number of times, none of the figures in the Book of Job, or their respective schools, claim that God acted unjustly, none deny divine justice. It is because they all assume divine justice that the characters disagree among themselves as to how to resolve that with Job's suffering and evil.

In order to work out Saadia's phenomenology of what is in the hearts of people when they suffer, let's begin with his interpretation of the narrative frame of the book, chs. 1-2.

According to its traditional literal meaning, Satan is God's quasi-divine mythical adversary, and the description "bnei ha-elohim" $(1,6)$, which is usually translated as "children/sons of God," traditionally refers to angellike, supernatural, quasi-divine figures, demi-gods, or other fabular beings in the divine court. After arguing against these supernatural interpretations, Saadiah instead offers his own naturalistic reading:

I rendered "bnei ha-elohim" as "God's beloved" (awliya' Allah; Kafih: nikhbadey hashem) in accordance with the widespread usage of the nation, as in Children are ye to the Lord your God (Deut. 14:1), My first-born child Israel (Exod 4: 22), Is corruption His? No, His children's is the fault (Deut. 32: 5), and the like. These beloved would gather in a special place on appointed days to worship God and do His bidding. ... The gathering was for worship of Him. ... As for the adversary ( $\operatorname{satan}$ ), he was in fact an ordinary human being, like the one mentioned when Scripture says, The Lord raised an adversary (satan) to Solomon, Hadad the Edomite (1 Kings 11:14) It also says, And God raised up against him an adversary (satan), Rezon, son of Eliada (I Kings 11:23). Both of these were mortal men. ... So commonly is this word (satan) applied to people who oppose one another that it occurs in many passages of Scripture which I shall not enumerate. ... On the basis 
of this and other parallels, the adversary here would be a human being. It is farfetched in the extreme to infer that he should be an angel. (Saadiah $1988,153-4)$

In other words, the bnei ha-elohim are humans who assemble to worship God and obey His laws; hence, they are intimates of and beloved by God. Likewise, Satan is Job's (not God's) adversary (Saadiah 1988, 154), and (based on v 6) also one of God's Beloved or nobles, hence, also a God-fearing and God-worshiping human but a special rival of Job, the leader of the Job-opposition party.

But Saadiah's naturalism does not stop here. His full explanation of Job's suffering is also naturalistic: in terms of human psychology and attitudes. As we said, the human bnei ha-elobim are sincere servants of God who shun sin and pursue virtue and, if they are not quite as virtuous as Job, nonetheless they are worthy to be loved by God, good people deserving happiness and a good life. But

with all Job's probity and plenty, there were folk in that land who envied him on both accounts, who said of him that he served God only out of solicitude for His blessings, and that if some disaster befell him or if he were deprived of some of those blessings, he would falter in his faithfulness and turn apostate. (Saadiah 1988, 159)

Notwithstanding the fact that they were also beloved by God, these same folks envied Job for his piety and prosperity. They charged that, as blameless as he was, he was pious, if not in order to receive the plenty, then only so long as he was blessed with plenty. That is, they raise the suspicion: does Job prosper because he is pious or is he pious only because he is prosperous?

According to Saadiah, it is "envy" that gives rise to this suspicion about Job. Who or what creates the envy? According to the literal meaning of v. 8 , the source is God Himself who singles out Job's exceptional blamelessness and God-fearingness- "for there is none like him in the land." In other words, among God's Beloved, all of whom worship God, all of whom are good people, God plays favorites - and rewards Job more than the others. What Saadiah is getting at, in more contemporary terms, is the basic inequity of distribution of goods in social life. Not everyone, even when they are all good and deserving, is treated or rewarded equally. Or at the very least not everyone perceives him/herself to be equally well 
treated as everyone else is. Someone will always take someone else to be better treated, more beloved, than she is. We cannot help but compare ourselves to others and ask the following: What did I do not to deserve the same great fortune he is receiving? If I am as good as that other person, why is she better off than me? This sort of envy is a source of suffering, hence, an evil.

But even worse than this suffering is the suspicion of others that envy breeds. In these circumstances, it is all too easy to suspect the credentials of others whom we perceive to be doing better than us, to accuse others of being good only because they receive goods, that they would not act as well if they were subject to more difficult circumstances-if they were subject to the difficult circumstances that each person believes is his lot in life despite his good behavior. Hence, others are always less, or at least no more, deserving than us. This delegitimation of others Saadiah calls "slander" or "defamation" (Saadiah 1988, 159), a kind of humanly inflicted violence, again, an evil.

This, I propose, is how Saadiah interprets the opening frame of the Book of Job. Job's world, for all of its pious obedience and worship, was a very unhappy place in which good people were nonetheless so jealous and envious of Job's pious success that they could not but suspect his motives and sincerity. The challenge the author of the Book of Job presents to usor that God faces-is: How, in such a world, can one prove the righteous person's, Job's, true and genuine piety and love and fear of God? The scenario Saadiah proposes is to make Job suffer. In Satan's words, he will then "falter in his faithfulness and turn apostate." Therefore, God inflicts Job to vindicate him of this charge. In more naturalistic terms, the Book of Job adopts what I call the "Thucydidean test."

In the various cities these revolutions were the cause of many calamities-as happens and always will happen while human nature is what it is, though there may be different degrees of savagery, and, as different circumstances arise, the general rules will admit of some variety. In times of peace and prosperity cities and individuals alike follow higher standards, because they are not forced into a situation where they have to do what they do not want to do. But war is a stern teacher; in depriving them of the power of easily satisfying their daily wants, it brings most people's minds down to the level of their actual circumstances. (Thucydides 1972, 242) $)^{5}$

\footnotetext{
${ }^{5}$ See also Reeve 1999.
} 
If we follow Thucydides' wisdom, in order to discover who humans really are, to expose true human nature and the authentic characters of humans, we should pinch them, put them under pressure: subject them to a plague, civil war, disease, loss of children, illness - in a word, suffering. Prosperity deceives or at least fails to expose the true self. Only when someone is desperate and suffering does she manifest who she really is. Only then, depending on how she endures or expresses herself in her suffering, can we tell whether she is as pious and deserving as she should be to receive goods and rewards. Happy circumstances leave open the question whether one is pious because she is prosperous or prosperous because she is pious. The function of suffering is to disambiguate or resolve this doubt.

However, as Saadiah goes on to interpret the story of Job, suffering alone does not disambiguate his situation. Thus I take part of the point of the Book of Job according to Saadiah to be a critique of the Thucydidean idea that suffering will unambiguously reveal the true self. Instead, suffering itself admits multiple interpretations and breeds its own ambiguities. Let me give you just one of a number of examples.

One would prima facie think that Elihu's theodicy of future compensation or reward is a good alternative to either incriminating Job (thereby making his suffering, punishment) or (allowing Job to be innocent) to rendering God arbitrary at best and unjust at worst. But in fact Elihu's theodicy creates a further ambiguity in suffering. On the table now are three disjuncts. Suffering can either be unjust persecution of Job despite his absolute innocence or punishment for prior sins or a trial to be compensated in the future. According to Saadia, no character or school in the Book of Job entertains the first disjunct: that God is unjust. With Elihu's intervention, however, that leaves two other disjuncts. Ambiguity persists. Whenever one suffers, one knows that it is either for one or for the other, but not which one. Hence, the Thucydidean test, suffering, fails to disambiguate Job's true piety. Beginning with ch. 37, Saadiah again and again emphasizes the ambiguity that accompanies Job's suffering, the fact that the victim must continually ask himself and ask God: Why am I suffering? The impossibility of clarification or disambiguation leads to isolation and alienation. Following Elihu's speech,

Job heard this discourse but held his peace, offering no rebuttal to Elihu. His silence at this point might indicate one of two things: either acquiescence or reservations. And it was for this reason that God addressed Him, to exhort to acknowledge Elihu's arguments and leave behind his fancies and 
suppositions, which in effect constitute his failing-although He does not say so directly, lest the people think little of Job's forbearance. (Saadiah 1988,379 )

Is Job silent because he accepts Elihu's explanation for his sufferingsilence is assent-or is he silent because he is silenced by Elihu-that is, overpowered by his rhetoric and too exhausted to fight it, though he resents and rejects it in his heart-or perhaps he is simply unsure? According to Saadiah, the question before God, as it were, is as follows: How will Job be perceived and judged by his fellow humans? God knows what Job feels, but it is necessary that Job publically articulate his reasoned acceptance of suffering for and to other humans if he is to disambiguate and thereby vindicate his piety. This in turn forces God to address Job in order to make him publically acknowledge Elihu's theodicy. And we would prima facie think that God's own speech to Job is unambiguous. But it isn't. Recall that Job has repeatedly pleaded with God to respond to his suffering by either killing him or by revealing his sin to him. God's lack of response, His silence, has only increased Job's lonely suffering. And when God finally speaks to Job from the whirlwind, Saadiah argues that what literally appears to be God extolling His all-powerfulness and control of Creation, is in fact, a new kind of silence.

Job had tried to understand why God tormented him and had entreated God to make the reason known to him [See 23: 3-5]. ... But God did not make this known to him. Sifting through many of the accounts of the ancients, we find that whenever one of them was afflicted by God in some way, and then asked his Lord to make known to him why that misfortune had been loosed upon him, we find a division: if the victim had suffered deservedly, God made it clear to him and told him, "This is for your wrong doing." ... But if the sufferer was being tested and had committed no offense to begin with, God did not explain his sufferings, so as not to undermine his forbearance in people's eyes... This is the pattern with those who are undergoing a trial. God does not directly inform them that they will be recompensed. Rather they must persevere on the basis of their reason alone.... So when Job asked his Lord to make known to him why He tormented him, God did not answer him about that but spoke to him instead about something else, describing Himself to him in terms of His power and greatness, and His choosing what is best for all creation. And this answer on God's part was one mark of His wisdom. (Saadiah 1988, 383-384) 
God's "silence" - his blank refusal to answer Job's question: Why am I suffering?-is His four-chapter-long and very loud speech extolling His power and beneficence. In reality, Saadia writes, this very speech is a demonstration of God's powerlessness. God cannot tell Job why he is suffering-as a trial to prove his piety that in turn will be compensated in the future-because were He to reveal that reason, people would say that Job accepts his suffering only to receive that reward-thereby undermining the test and injuring Job yet again. Thus God is constrained to be silent about the one thing Job wants to know-constrained by His own creation, other humans' perceptions, and the implications of His own speech. All of God's talk about His all-powerfulness is a mask to conceal His powerlessness. To be sure, this also makes Job suffer, but perhaps it is the lesser of the evils God would have committed had He explicitly answered him.

What exactly is it for Saadiah for humans "to persevere on the basis of their reason alone"? I don't have a full answer to this question but one thing emerges in God's speech. According to Saadia,

When God says, I shall ask thee $(38,30)$, it does not mean that God is giving him the power to answer as he pleases. Rather He is requiring Job to answer truthfully, that is, to submit (altaslim) to Him. (Saadiah 1988, 396)

First, when challenged, as in a debate-and Saadiah uses here terminology like altaslim and mas'ala drawn from the logical language of dialectic-one perseveres by reason by committing or submitting oneself to the challenger's question, responding explicitly and openly according to the demands and standards of truth as revealed by reason and science. One does not evade or ignore the challenge. One takes it up and responds.

Second, by "perseverance on the basis of reason alone" Saadiah also seems to mean that one should follow her reason even when it leads to uncertainty, doubt, and more suffering. When God has completed His speech, describing His wisdom manifest in nature, Saadiah tells us

Since the word had descended upon Job from God, it seemed best to him to hold his peace and say nothing. He supposed that such would be the proper behavior for one who submitted to Him. This called for a second address by God, making known to Job that discourse (al-kalam) was preferable. (Saadiah 1988, 396-7) 
I take Saadiah to mean that Job's silence after God's speech, like his silence after Elihu's speech, is still ambiguous, so, God forces Job in ch. 40 to speak to disambiguate "the thoughts in his heart." But even so, Job does not speak unambiguously:

What he says can bear two different senses. This statement of Job's was ambiguous. It does not convey to the hearer a clear idea of his meaning. One who says to someone who confronts him, "Truly, I cannot answer you," could be understood in two ways: either he is admitting the justice of the other's position and saying that he is not prepared to refute the truth, or he could be implying that the other is in the wrong, and saying, "How can I refute you when you have the upper hand?" (Saadiah 1988, 402)

Now, Job's speech, rather than his silence, is ambiguous. And "by suggestion he is impugning divine justice." And for yet a third time, this ambiguity repeats itself in ch. 41 when Job again does not speak. According to Saadiah,

[God says to Job:] 'As long as you leave your answer in suspense, you are in fact impugning My justice while holding yourself blameless.' The fruit of this utterance should be for Job to make a clear statement before his Lord, explaining to all who hear him that he acknowledges that God is the Alljust, who does no injustice, and that it is imperative to admit that He treats His servants only as is best. And that is what Job does. (Saadiah 1988, 408-9)

Ambiguity persists in both silence and speech. True submission (taslim) requires explicit acknowledgment through a confession of impotence, ignorance, or limitations on one's knowledge, and regret-all aspects of repentance. This is what Job finally delivers in ch. 42 .

In this passage Job combines all that was required of him: he confesses his impotence and his paltry ability to comprehend the grace in the governance and decree of the Allwise; he repents of what has passed ... and he resigns himself submissively (yaslam) to God, taking solace for himself. (Saadiah $1988,410)$

The ending of the book is reconciliation of Job with God-reconciliation depicted as a complex act of repentance. But this is not repentance for a sin he committed but a confession of his finite condition, his being a creature of creation, and his inability to comprehend the benevolence in the 
governance of God, which is accompanied by regret (haratah) and rejecting, or spurning, of his previous state, and submission, yielding solace.

However, Job's repeated ambiguous remarks underscore the problematics of ambiguity as an expression of his own mental suffering and of the evil he experiences. As long as he is not explicit, whether in speech or in silence, he is perceived as "controverting" God's justice. Although Job is innocent, he cannot state "I am innocent" because that would implicate that God is guilty, hence, unjust. So, to avoid that implicature, Job must do one of two things, neither of which is true to himself. Either he can say that he is guilty-but that would violate his own integrity. Or he must explicitly acknowledge that God is just and only acts for his creatures' good (408), which effectively belies his own suffering, re-describing the evil he experiences as a divine good.

What, then, "is in the hearts of people when they reach the limits of endurance in a trial"? First and foremost: repeated instances of ambiguity, both of silence and of speech, both about why one is suffering and about how to react. As we said, ambiguity is a species of doubt, and doubt is an epistemic evil. I am tempted to say that for Saadiah, Job's suffering state of mind and doubt replaces the earlier bodily, material, familial, and physical evils he suffered. The inner state of epistemic evil-how Job thinks about his external suffering-replaces the external evil of physical and material suffering. But the evil is twofold. First, the ambiguity allows others to continue to impugn Job's piety, which is yet another moral evil inflicted on Job. Second, the ambiguity reflects Job's own state of mind, his uncertainty, anxiety, isolation, and powerlessness due to his ignorance of why he is suffering and how he should react. But this kind of inability to understand God's justice and governance is not because God's will is incomprehensible, as it is for the Ash'arite. Job's lack of understanding is an achievement of his own reason, not a surrender. Job's reason leads him to its limits, but at the same time he is empowered by it to fulfill the obligation of submission or commitment to God-to explicitly, propositionally, discursively articulate in the third person what he is thinking. This kind of submission, and consequent reconciliation, not a theodicy, is what the Book of Job teaches us and that is the reason why it was written:

[God] caused their [Job's and the other friends'] history to be written as a lesson to all creation, so that we may bear sufferings with fortitude when they befall us and not hasten to impugn God's judgment but submit to God and accept His wisdom and direction. (Saadiah 1988, 410) 


\section{BIBLIOGRAPHY}

al-Muqammas, Dawud ibn Marwan. 2016 (9th c.). Twenty Chapters ('Ishrun Maqala) The Judeo-Arabic Text Transliterated into Arabic Characters, with a Parallel English Translation, Notes, and Introduction. Translated, notated, and introduced by Sarah Stroumsa. Provo: Brigham Young University Press.

Brody, Robert. 2016. Sa'adyah Gaon. London: Littman Library of Jewish Civilization.

Cohen, Mordechai Z. 2005. Maimonides' Literary Approach to the Book of Job and Its Place in the History of Biblical Interpretation [Hebrew]. Shnaton: An Annual for Biblical and Ancient Near Eastern Studies XV: 213-264.

Eisen, Robert. 2004. The Book of Job in Medieval Jewish Philosophy. Oxford: Oxford University Press.

Goodman, Lenn E. 1990. Saadiah Gaon's Interpretive Technique in Translating the Book of Job. Jewish Quarterly Review Supplement: 47-76.

Heschel, Abraham. 1942-3. The Quest for Certainty in Saadia's Philosophy. Jewish Quarterly Review 38: 265-313.

- 1944. Reason and Revelation in Saadia's Philosophy. Jewish Quarterly Review 39: 391-408.

Hume, David. 1779 (1993). Dialogues Concerning Natural Religion and the Natural History of Religion, ed. J.C.A. Gaskin. Oxford: Oxford University Press.

Maimonides, Moses. 1965. Guide of the Perplexed. 2 Vols. Translated by Shlomo Pines. Chicago: University of Chicago Press.

Malter, Henry. 1921. Saadia Gaon: His Life and Works. Philadelphia: Jewish Publication Society of America.

Nadler, Steven. 2009. Theodicy and Providence. In The Cambridge History of Jewish Philosophy: From Antiquity Through the Seventeenth Century, ed. Steven Nadler and T.M. Rudavsky, 619-658. New York/Cambridge: Cambridge University Press.

Reeve, C.D.C. 1999. Thucydides on Human Nature. Political Theory 27 (4): 435-446.

Rosenthal, E.I.J. 2001. Saadya's Exegesis of the Book of Job. In Judaism, Philosophy, Culture, ed. Erwin Rosenthal, 97-125. New York: Curzon Press.

Saadiah Ben Joseph Al-Fayyumi Gaon. 1946/2002. The Book of Doctrines and Beliefs (Selections). Translated by Alexander Altmann. Repr. Indianapolis: Hackett.

—. 1948. The Book of Doctrines and Opinions. Translated by Samuel Rosenblatt. New Haven: Yale University Press.

. 1972. Sefer Ha-Nivhar be-Emunot ve-De'ot. Arabic text with Hebrew translation. Translated by R. Joseph Kafih. Jerusalem: Sura.

. 1973. Iyov: Sepher Ha Yashar. Hebrew translation with the Judeo-Arabic Text and Commentary. Translated by R. Joseph Kafih. Jerusalem/New York: Sura. 
1988. The Book of Theodicy: Translation and Commentary on the Book of Job. Translated by Lenn E. Goodman. New Haven: Yale University Press.

Stern, Josef. 2017. What a Jewish Philosophy Might Be (If It Exists): A View from the Middle Ages. Iyyun: The Jerusalem Philosophical Quarterly 66: 227-257.

Stroumsa, Sarah. 2003. Saadya and Jewish Kalam. In Cambridge Companion to Medieval Jewish Philosophy, ed. Daniel Frank and Oliver Leaman, 71-90. Cambridge: Cambridge University Press.

Stump, Eleonore. 1997. Saadia Gaon on the Problem of Evil. Faith and Philosophy 14: 523-549.

- 2000. The God of Abraham, Saadia, and Aquinas. In Referring to God: Jewish and Christian Philosophical and Theological Perspectives, ed. Paul Helm, 95-128. Richmond: Curzon.

- 2010. Wandering in Darkness. Oxford: Oxford University Press.

Thucydides. 1972. Thucydides: The Peloponnesian War. Translated by Rex Warner. New York: Penguin.

Weiss, Roslyn. 2000. Saadiah on Divine Grace and Human Suffering. The Journal of Jewish Thought and Philosophy 9: 155-171.

Open Access This chapter is licensed under the terms of the Creative Commons Attribution 4.0 International License (http://creativecommons.org/licenses/ by $/ 4.0 /$ ), which permits use, sharing, adaptation, distribution and reproduction in any medium or format, as long as you give appropriate credit to the original author(s) and the source, provide a link to the Creative Commons licence and indicate if changes were made.

The images or other third party material in this chapter are included in the chapter's Creative Commons licence, unless indicated otherwise in a credit line to the material. If material is not included in the chapter's Creative Commons licence and your intended use is not permitted by statutory regulation or exceeds the permitted use, you will need to obtain permission directly from the copyright holder.

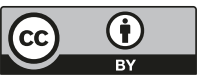

